\title{
'Silver' trauma: predicting mortality in elderly major trauma based on place of injury
}

\author{
Susan A Hendrickson*, Denise Osei-Kuffour, Christopher Aylwin, Michael Fertleman, Shehan Hettiaratchy \\ From London Trauma Conference 2014 \\ London, UK. 9-12 December 2014
}

\section{Background}

Elderly trauma now accounts for more than $20 \%$ of UK major trauma [1]. Clearly, elderly trauma patients are at increased risk of morbidity and mortality, but outcome can be difficult to predict. Current evidence is limited to correlations between poor outcome and complex, difficult-to-calculate pre-morbid frailty indices [2]. A simple, evidence-based prognostic marker is needed to guide early management. We hypothesised that elderly patients suffering severe injury at home indoors are frailer, and therefore more likely to succumb to their injuries, than those injured outdoors.

\section{Method}

All patients admitted to a London major trauma centre in 2013 aged $\geq 65$ years old with an Injury Severity Score (ISS) $>15$ were identified using Trauma Audit \& Research Network data. Patient demographics, date of death, and injury location ('at home indoors' or 'outside the home') were recorded and mortality rates compared.

\section{Results}

124 patients were included (M:F = 1.4:1). 58 patients $(46.8 \%)$ were injured at home indoors; 66 patients (53.2\%) outside the home. The groups were equivalent in age $(\mathrm{p}=0.44)$ and ISS $(\mathrm{p}=0.52) .6$-month mortality among patients injured at home indoors was $36.2 \%$, nearly double that of patients injured outside of the home $(18.2 \%)(\mathrm{p}=0.0267)$.

\section{Conclusion}

Our study found significant correlation between injury location and mortality, suggesting that severe injury inside the home could represent a rough marker of

\footnotetext{
* Correspondence: susanahendrickson@gmail.com

Major Trauma Centre, St. Mary's Hospital, Imperial College Healthcare NHS Trust, London, UK
}

(c) 2015 Hendrickson et al. This is an Open Access article distributed under the terms of the Creative Commons Attribution License (http://creativecommons.org/licenses/by/4.0), which permits unrestricted use, distribution, and reproduction in any medium, provided the original work is properly cited. The Creative Commons Public Domain Dedication waiver (http://creativecommons.org/ publicdomain/zero/1.0/) applies to the data made available in this article, unless otherwise stated.

\section{and take full advantage of:}

- Convenient online submission

- Thorough peer review

- No space constraints or color figure charges

- Immediate publication on acceptance

- Inclusion in PubMed, CAS, Scopus and Google Scholar

- Research which is freely available for redistribution

Submit your manuscript at Submit your manuscript at C BioMed Central 